\title{
THE EFFECT OF GLASS UPON THE ACTIVITY OF THE VARIOUS PLASMA CLOTTING FACTORS
}

\author{
By SAMUEL I. RAPAPORT,1, 2 KNUT AAS, AND PAUL A. OWREN \\ (From the Department of Medicine, Oslo University Hospital, Oslo, Norway)
}

(Submitted for publication June 18, 1954; accepted September 29, 1954)

Contact of the blood with a foreign surface such as glass initiates clotting not only by disruption of platelets but by the activation of plasma clotting factors. Many explanations have been advanced for the increased coagulability of the plasma. Contact with glass has been said to remove a lipid antithromboplastin (anti-cephalin) (1-3), to remove a protein inhibitor of prothrombin (4-6), to activate a plasma thromboplastin precursor (7-10), more specifically, the antihemophilic $B$ factor (Christmas factor ${ }^{3}$ ) (11), and to convert an in-

\footnotetext{
1 Fulbright Research Scholar, Department of Medicine, Oslo University, 1953-1954.

2 Present Address : Hematology Section, Veterans Administration Hospital, Long Beach, California.

8 There is no standard nomenclature for the newer clotting factors. The following terms are used in this paper. Blood thromboplastin is used in its classic meaning of an activity which arises during clotting and which is equivalent in effect to the clotting activity of aqueous tissue extracts. Antihemophilic $A$ factor is the name used for the plasma thromboplastin precursor present in Seitz filtered or barium carbonate absorbed fresh normal plasma, absent from the plasma of most patients with hemophilia and not found in aged normal serum; synonyms are anti-hemophilic globulin and thromboplastinogen. Antihemophilic $B$ factor is the name used for a different plasma thromboplastin precursor which is found in aged normal serum, is absent from the plasma of an occasional patient with otherwise classical hemophilia and is not found in Seitz filtered or barium carbonate adsorbed fresh normal plasma. Synonyms are plasma thromboplastin component (PTC), plasma thromboplastin factor-B (PTF-B), Christmas factor. Proconvertin is the name given to a stable prothrombin converting substance which can be demonstrated in normal plasma and serum. The terms used to describe proconvertin activity and the relation of proconvertin to convertin are discussed in detail in the body of this paper. Synonyms for proconvertin or for mixtures of proconvertin and convertin are SPCA, Factor VII, and Stable Factor. Proaccelerin is the name used for the labile accelerator of thrombin formation found in Seitz filtered or barium carbonate adsorbed fresh plasma but not found in aged serum; synonyms are plasma AC globulin and Labile Factor. Accelerin is the name used for the increased accelerator activity which is produced by adding a small amount of thrombin to adsorbed plasma; synonym is serum AC globulin.
}

active precursor of prothrombin (prothrombinogen) to active prothrombin (12). Furthermore, the effect of glass has been attributed to minute amounts of thrombin adsorbed onto the glass (13). In a preliminary note (14), we said that contact of plasma with glass increases the activity of both the antihemophilic B factor and proconvertin. The present paper describes and discusses in greater detail the experiments which support this statement.

The idea of a plasma thromboplastin precursor activated by contact with a foreign surface is not new. Lenggenhager postulated in 1935 (15) that blood thromboplastic activity arose after contact of an inactive plasma precursor with a foreign surface in the presence of calcium. Lozner, Taylor, and MacDonald presented data in 1942 (16) which strongly suggested that glass could activate a plasma thromboplastin precursor in citrated plasma. Conley and Hartmann and their coworkers (7-9), and Quick and Epstein (10) presented further evidence for the glass activation of a plasma thromboplastin precursor. With the demonstration and characterization of two plasma thromboplastin precursors $(17,18)$ the question arose as to which one the glass influenced. The recent experiments of Biggs, Douglas, and Macfarlane (11) indicate it is the antihemophilic B factor.

There is also evidence that contact with glass activates a plasma factor not involved in blood thromboplastin formation. When a Quick "prothrombin time" is done upon plasma which has stood for several days in glass, and to which proaccelerin has been added to replace that which deteriorates during standing, the resultant clotting time may be shorter than that of the freshly prepared plasma. This cannot be due to the activation of a plasma thromboplastin precursor, for the excess brain extract thromboplastin which is added in a Quick test would mask this effect. Quick and Stefanini (12) and, more recently, Lewis and Ware (19) state that the shortening is caused by 
the activation of prothrombin, a return to the early hypothesis of Bordet that prothrombin circulates in an inactive form which must be altered by contact with a foreign surface before clotting will occur. However, Alexander and Landwehr (20), who investigated the same phenomenon, explain the shortening by the evolution of proconvertin activity (SPCA) due not to an effect of the glass but to a slow "coagulation" of the plasma on standing.

Biggs and Macfarlane state in their book (21) that contact with glass during clotting accelerates the formation of proconvertin (Factor VII) from a precursor in the plasma. This statement stems from the observation, reported earlier by Alexander, DeVries, and Goldstein (22), that the proconvertin activity of serum from blood which has clotted in silicone coated tubes is less than that of serum from blood clotted in contact with glass. Alexander also showed that the addition of tissue thromboplastin to the blood increases the proconvertin activity of the resultant serum. Therefore, the increased proconvertin activity of serum from blood clotted in contact with glass could be an indirect effect secondary to the greater blood thromboplastin formation in glass, rather than a direct effect of the glass upon proconvertin. In fact, in their recent paper which describes the effect of glass upon antihemophilic B factor activity (11), Biggs, Douglas, and Macfarlane reverse their former opinion and state that glass contact does not increase proconvertin (Factor VII) activity.

In our experiments the clotting behaviour of freshly drawn, citrated, platelet poor plasma exposed only to silicone surfaces was compared with that of plasma prepared the same but shaken for 15 minutes with approximately $1 / 4$ its volume of fine quartz glass powder. One group of experiments measured only the effect of this procedure upon the plasma thromboplastin precursors in one-stage assays modeled after that of Langdell, Wagner, and Brinkhous (23). In a second group of experiments strong brain extract thromboplastin was added to the plasma. This eliminated any manifestations of the effect of glass upon the plasma thromboplastin precursors. The clotting behaviour of the two types of plasma were compared in the specific one-stage systems of Owren and Aas $(24,25)$ for prothrombin, proconvertin, and proaccelerin.

\section{REAGENTS}

A. For the assay of antihemophilic $A$ and antihemophilic $B$ factor activity

Hemophilia A plasma was obtained from a patient with the classical clinical findings of severe hemophilia and a coagulation defect which was corrected by oxalated barium sulfate adsorbed plasma but not by old serum. Hemophilia $B$ plasma was obtained from a patient who also exhibited the classical clinical findings of severe hemophilia but whose coagulation defect was corrected by hemophilia A plasma and by old serum but not by oxalated barium sulfate adsorbed plasma. Blood from these patients was collected directly into chilled, silicone coated centrifuge tubes which contained 1 volume of 0.1 $M$ sodium citrate for each 9 volumes of blood and centrifuged at $2,500 \mathrm{rpm}$ and $2^{\circ} \mathrm{C}$. for 40 minutes. The plasma was then transferred to lusteroid tubes with silicone coated pipettes and centrifuged for about 20 minutes at either 10,000 or $20,000 \mathrm{rpm}$ in an ultracentrifuge. The resultant platelet poor plasma was mixed with $1 / 4$ its volume of fine quartz glass powder (Quarz, gewaschen u. gegluht, E. Merck, Darmstadt, which had been ground in a glass mill to give particles of diameter less than $0.068 \mathrm{~mm}$.). After 15 minutes the quartz powder was removed by centrifugation at $2,500 \mathrm{rpm}$ for 10 minutes. The "glass activated" hemophilic plasmas were then divided into small aliquots which were stored frozen at $-20^{\circ} \mathrm{C}$. for periods up to three months. The plasmas were used within about an hour after defrosting. They were checked and found to have a normal content of prothrombin and proconvertin and a slightly reduced but adequate amount of proaccelerin.

Normal plasma. Nine volumes of venous blood were collected directly into a chilled, silicone coated centrifuge tube which contained 1 volume of $0.1 \mathrm{M}$ sodium citrate, and centrifuged for 40 minutes at $2,500 \mathrm{rpm}$ at $2^{\circ} \mathrm{C}$. A portion of the resultant platelet poor plasma was transferred to a silicone coated tube for use as the sample of "silicone" plasma. The remaining plasma was shaken with quartz glass powder as described above to prepare the sample of "glass activated" plasma. On one occasion the glass activation was accomplished by the addition of 10 small glass beads (diameter $4 \mathrm{~mm}$.) to $2 \mathrm{ml}$. of plasma followed by continuous shaking for 15 minutes. All plasma samples were tested within about 4 hours after the blood was drawn.

Adsorbed ox plasma. Citrated ox plasma was filtered once through a 20 per cent asbestos filter and twice through a 50 per cent asbestos filter using a technique published earlier (24). Such plasma is free of prothrombin, proconvertin, and antihemophilic B factor but contains large amounts of proaccelerin, antihemophilic A factor, and fibrinogen. 
"Cephalin." An acetone insoluble, ether extract of human brain was prepared according to the technique of Milstone (26). A description of our preparation has been given elsewhere (27). Small aliquots of a $2.2 \mathrm{gm}$. per cent suspension of lipid in veronal buffer were stored frozen at $-20^{\circ} \mathrm{C}$. Before use these were diluted 1 to 20 or 1 to 30 with veronal buffer to give a $0.11 \mathrm{gm}$. per cent or a $0.07 \mathrm{gm}$. per cent lipid suspension.

Citrate-saline. This was made by mixing 1 part of 0.1 $M$ sodium citrate with 5 parts of physiological saline.

Veronal buffer. A modified veronal buffer of $\mathrm{pH} 7.35$ and ionic strength 0.154 was prepared as described elsewhere (27).

Calcium. A $0.030 \mathrm{M}$ solution of calcium chloride was used.

B. For the measurement of prothrombin-proconvertin $(P \& P)$, prothrombin, proconvertin, and proaccelerin activity

Normal "silicone" and "glass activated" plasmas were prepared as above.

Proconvertin deficient plasma was obtained from a patient with a congenital deficiency of this factor. This plasma has a normal content of prothrombin and proaccelerin but only about 1 per cent proconvertin. The clotting behaviour of this plasma has been described in detail previously (25). Citrated plasma was stored in small lots at $-20^{\circ} \mathrm{C}$. and defrosted as needed.

Adsorbed ox plasma for use as proaccelerin reagent was prepared as described above but was filtered only once through 50 per cent asbestos. Accelerin reagent was prepared by adding a small amount of thrombin to the ox plasma. Dried thrombin ("Hemoclaudan," Lövens Kemiske Fabrik, Copenhagen) was made up in about $5 \mathrm{ml}$. of veronal buffer. Several drops were added to about $10 \mathrm{ml}$. of ox plasma and the resultant fibrin clot removed after several minutes. This dropwise addition of thrombin was repeated until no further fibrin formed. The defibrinated ox plasma was than incubated at $37^{\circ} \mathrm{C}$. for $30 \mathrm{~min}$ utes to inactivate the thrombin. This accelerin reagent gave a clotting time of 16 seconds in the proaccelerin system compared to a time of 25 seconds before the thrombin activation.

Serum. Prothrombin "free" serum was prepared by the addition of $0.3 \mathrm{ml}$. of saline brain extract thromboplastin for each $10 \mathrm{ml}$. of blood immediately after withdrawal followed by vigorous stirring for 10 minutes. After one hour the serum was removed and aged for 7 days at refrigerator temperature. It was then citrated with 1 volume of $0.1 \mathrm{M}$ sodium citrate per 5 volumes of serum and stored at $-20^{\circ} \mathrm{C}$.

Saline brain extract thromboplastin. A saline-buffer suspension of human brain was prepared by a method previously described (28):

Diluting fluid for the test plasmas was made by mixing $177 \mathrm{ml}$. of $0.034 \mathrm{M}$ sodium citrate, $200 \mathrm{ml}$. of veronal buffer and $673 \mathrm{ml}$. of physiological saline.

Calcium. A $0.030 \mathrm{M}$ solution of calcium chloride was used.

\section{METHODS}

\section{A. For the assay of the antihemophilic $A$ and $B$ factors}

When either normal or hemophilic plasma is recalcified in the presence of a strong saline brain extract thromboplastin, a clotting time of about 12 seconds is obtained. When a dilute ether extract of brain, the usual "cephalin" preparation, is substituted for the saline extract, normal plasma, after contact with glass, will clot in 40 to 80 seconds. The "cephalin" is an incomplete thromboplastin which is thought to supply only the equivalent of the platelet lipoid factor. The extra time is consumed by a preliminary reaction between the "cephalin" and the antihemophilic A and B factors to form plasma thromboplastin. When "cephalin" is added to hemophilic plasma which has been in contact with glass, a clotting time of 150 to 300 seconds is usually obtained. The longer clotting time is caused by a deficiency of one of the plasma thromboplastin precursors in the hemophilic plasma.

The long "cephalin" clotting time of hemophilic plasma can be shortened by adding dilute normal plasma to the hemophilic plasma. This is the basis for the assay for "anti-hemophilic factor" proposed by Langdell, Wagner, and Brinkhous (23). Their method may be used to assay either the antihemophilic A factor or the antihemophilic B factor by choosing either hemophilia A or hemophilia B plasma as the starting reagent. Furthermore, if these hemophilic plasmas are shaken with glass powder in their preparation they should each provide a relative excess in "glass activated" form of every plasma clotting factor except the plasma thromboplastin precursor which each lacks. The hemophilic plasmas can then be used as reagents to measure the effect of glass activation upon the antihemophilic factors. For example, hemophilia B plasma, after exposure to glass powder, should contain every plasma clotting factor in "glass activated" form except the antihemophilic B factor. Therefore, the determination of the shortening produced in the "cephalin" clotting time of the "glass activated" hemophilia B plasma by the addition of a given dilution first of normal "silicone" plasma and then of normal "glass activated" plasma should be a measure of whether or not exposure to glass changes the activity of the antihemophilic $B$ factor.

Our procedure was to mix, in the order listed, $0.2 \mathrm{ml}$. of "cephalin," $0.2 \mathrm{ml}$. of "glass activated" hemophilia A or B plasma and $0.2 \mathrm{ml}$. of a dilution of either "silicone" or "glass activated" normal plasma. The mixture was incubated at $37^{\circ} \mathrm{C}$. for 3 to 5 minutes and then $0.2 \mathrm{ml}$. of calcium chloride was added. In the antihemophilic $\mathbf{A}$ factor assay the normal plasma was diluted only in citrate-saline solution. In the antihemophilic $B$ factor assay the final 1 to 5 dilution of normal plasma was made in adsorbed ox plasma to provide extra antihemophilic $A$ factor and proaccelerin. When the effect of "silicone" plasma was being measured, only silicone technique was used.

The clotting times in both assay systems often varied with different normal plasmas. Therefore, a "normal" 
dilution curve was not used to calculate different samples as per cent of normal. Each plasma was compared only with itself. For each plasma a 1/10 dilution of "silicone" plasma was compared with a $1 / 10$ dilution of "glass activated" plasma and with at least one other dilution of the "glass activated" plasma. This gave rough quantitative meaning to differences in the clotting times of the $1 / 10$ dilutions of the two kinds of plasma.

\section{B. For the measurement of the prothrombin-proconvertin $(P \& P)$ time, the proconvertin time, the prothrombin time and the proaccelerin time}

The principles and methods for the one stage determination of the $\mathbf{P} \& \mathbf{P}$ time, the proconvertin time, the prothrombin time, and the proaccelerin time have been described in detail previously $(24,25)$.

The $P$ \& $P$ time is obtained by mixing $0.2 \mathrm{ml}$. of a $1 / 10$ dilution of test plasma with $0.2 \mathrm{ml}$. of adsorbed ox plasma, $0.2 \mathrm{ml}$. of brain thromboplastin and $0.2 \mathrm{ml}$. of calcium chloride. Every known clotting factor is then in excess except for prothrombin and proconvertin whose content in the test plasma is measured.

The original proconvertin time method has been modified by the use of plasma from a patient with congenital hypoproconvertinemia. The assay system now consists of $0.2 \mathrm{ml}$. of hypoproconvertinemia plasma (supplies prothrombin in excess), $0.2 \mathrm{ml}$. of adsorbed ox plasma (supplies proaccelerin in excess), $0.2 \mathrm{ml}$. of a $1 / 10$ dilution of the test plasma, $0.2 \mathrm{ml}$. of brain thromboplastin and $0.2 \mathrm{ml}$. of calcium chloride. The clotting time then reflects the proconvertin content of the test plasma.

The specific prothrombin time is determined by mixing $0.2 \mathrm{ml}$. of specially prepared prothrombin "free" serum (supplies proconvertin in excess), $0.2 \mathrm{ml}$. of ox plasma (supplies proaccelerin in excess), $0.2 \mathrm{ml}$. of a $1 / 10$ dilution of the test plasma, $0.2 \mathrm{ml}$. of brain thromboplastin and $0.2 \mathrm{ml}$. of calcium chloride. Variation in the clotting time of this system will depend only upon the prothrombin content of the test plasma.

The proaccelerin time is measured by mixing $0.2 \mathrm{ml}$. of parahemophilia plasma (supplies prothrombin and proconvertin in excess), $0.2 \mathrm{ml}$. of a 1/20 dilution of the test plasma, $0.2 \mathrm{ml}$. of brain thromboplastin and $0.2 \mathrm{ml}$. of calcium chloride. The clotting time obtained will vary with the proaccelerin content of the test plasma.

\section{RESULTS AND DISCUSSION}

A. The effect of contact with glass upon the activity of the antihemophilic $A$ and $B$ factors

A representative sample of the data secured when normal "silicone" and "glass activated" plasmas were compared in the antihemophilic A factor assay are given in Table I. These data show no consistent difference between the clotting times obtained when a $1 / 10$ dilution of either "silicone" or "glass activated" plasma is added to
TABLE I

A comparison of the clotting times of "silicone" plasma and "glass activated" plasma in the hemophitia $A$ assay system

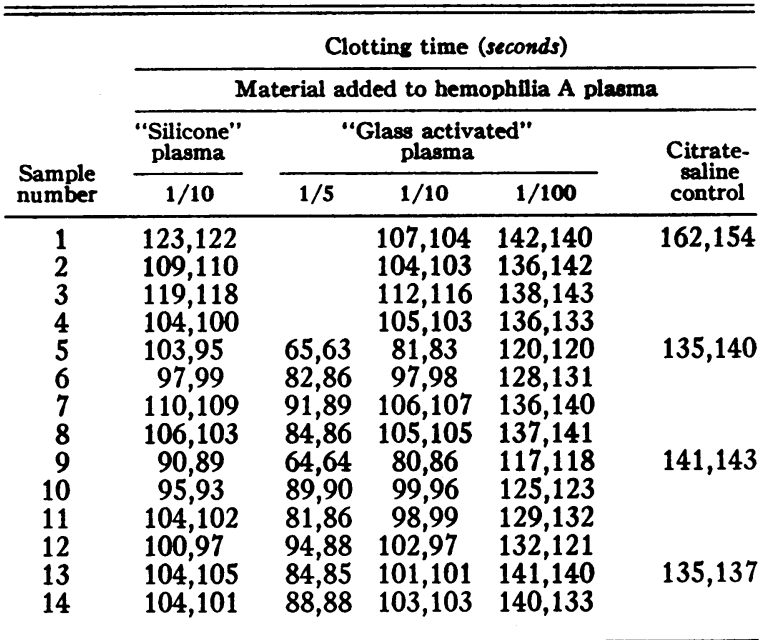

hemophilia A plasma. An occasional plasma, e. g., samples 1 and 5 , shows some suggestive increase in activity after "glass activation," but the majority of clotting times are the same for either type of plasma.

Table II summarizes data obtained when normal "silicone" and "glass activated" plasmas were compared in the antihemophilic B factor assay. In contrast to the data of Table I, normal "glass activated" plasma was consistently more effective than normal "silicone" plasma in shortening the clotting time of hemophilia B plasma. Moreover, a comparison of the clotting times of the $1 / 100$ dilution of "glass activated" plasma with the $1 / 10$ dilution of "silicone" plasma shows that glass contact may increase antihemophilic B factor activity more than ten-fold. These findings confirm those of Biggs, Douglas, and Macfarlane (11) and suggest that the antihemophilic $B$ factor may exist in the blood largely, and perhaps entirely, in an inactive form.

Recently, Tocantins (3) has stated that there is only one plasma thromboplastin precursor. This is covered by an inhibitor which contact with a foreign surface removes. Tocantins believes that in hemophilia A there is a normal amount of this thromboplastin precursor but an excess of inhibitor, whereas in hemophilia $B$ the plasma is deficient in both the thromboplastin precursor and the inhibitor. 
This theory will not fit our observations. "Glass activated" hemophilia A plasma still possesses an abnormally long "cephalin" clotting time which is corrected equally well by normal "silicone" and "glass activated" plasma. If there were only one plasma thromboplastin precursor, partly inactivated in its native state by an inhibitor absorbed by glass, then "glass activated" plasma should be more effective than "silicone" plasma in both the antihemophilic A and the antihemophilic B factor assay. Furthermore, asbestos filtered ox plasma contains no antihemophilic B factor but has a normal content of antihemophilic A factor which would have been activated by the asbestos (1). However, the addition of a 1/5 dilution of adsorbed ox plasma to normal "silicone" plasma will not shorten its long "cephalin" clotting time of about 200 seconds (see Table IV). In contrast, the addition of a $1 / 5$ dilution of "glass activated" hemophilia A plasma produces an appreciable shortening. Our observations, therefore, add to the evidence that at least two plasma thromboplastin precursors exist, only one of which, the antihemophilic B factor, is activated by glass.

\section{B. The effect of glass upon proconvertin ac- tivity}

1. The evidence that glass activates a factor in addition to the antihemophilic $B$ factor

The clotting activity of strong brain thromboplastin is equivalent to the combined effect of

TABLE II

A comparison of the clotting times of "silicone" plasma and "glass activated" plasma in the hemophilia

$B$ assay system

\begin{tabular}{|c|c|c|c|c|}
\hline \multirow{4}{*}{$\begin{array}{c}\text { Sample } \\
\text { no. }\end{array}$} & \multicolumn{4}{|c|}{ Clotting time (seconds) } \\
\hline & \multicolumn{4}{|c|}{ Material added to hemophilia B plasma } \\
\hline & \multirow{2}{*}{$\begin{array}{c}\text { "Silicone" } \\
\text { plasma } \\
1 / 10\end{array}$} & \multicolumn{2}{|c|}{$\begin{array}{c}\text { "Glass activated" } \\
\text { plasma }\end{array}$} & \multirow{2}{*}{$\begin{array}{c}\text { Adsorbed } \\
\text { ox } \\
\text { plasma } \\
\text { control }\end{array}$} \\
\hline & & $1 / 10$ & $1 / 100$ & \\
\hline $\begin{array}{r}1 \\
2 \\
3 \\
4 \\
5 \\
6 \\
7 \\
8 \\
9 \\
10 \\
11 \\
12\end{array}$ & $\begin{array}{r}116,113 \\
114,114 \\
99,102 \\
118,126 \\
154,161 \\
137,131 \\
124,123 \\
152,145 \\
154,153 \\
140,141 \\
124,116 \\
166,162\end{array}$ & $\begin{array}{c}76,81 \\
54,51 \\
59,61 \\
110,111 \\
104,99 \\
78,80 \\
65,67 \\
103,101 \\
120,120 \\
128,121 \\
96,105 \\
127,134\end{array}$ & $\begin{array}{c}104,102 \\
85,81 \\
92,93 \\
151,152 \\
= \\
122,119 \\
150,144 \\
165,166 \\
169,163 \\
137,133 \\
166,166\end{array}$ & $\begin{array}{l}199,199 \\
195,198\end{array}$ \\
\hline
\end{tabular}

TABLE III

The Quick "prothrombin time" of "silicome" and "glass activated" plasmas deficient in different precursors of blood thromboplastin

\begin{tabular}{lcc}
\hline \hline & \multicolumn{2}{c}{ Clotting time (seconds) } \\
\cline { 2 - 3 } Type of plasma & "Silicone" & $\begin{array}{c}\text { "Glass } \\
\text { activated" }\end{array}$ \\
\hline Normal plasma & 17.4 & 11.2 \\
Platelet rich & $\overline{12.2}$ & 11.4 \\
Platelet poor* & 12.2 & 9.6 \\
Hemophilia A & 18.4 & 12.8 \\
Hemophilia B & & \\
Platelet poor* & & \\
\hline
\end{tabular}

* Centrifuged at $10,000 \mathrm{rpm}$ for 40 minutes.

platelet lipoid factor, antihemophilic $\mathrm{A}$ factor and antihemophilic B factor. Therefore, a difference in the clotting times of "silicone" and "glass activated" plasma with excess strong brain thromboplastin, as in a Quick "prothrombin time," must mean that glass activates a factor in addition to the antihemophilic B factor. It also implies that the activation of this second factor does not depend upon the activation of the antihemophilic $B$ factor nor upon the generation of a small amount of blood thromboplastin. The data in Table III support this view for they show that glass powder can shorten the Quick "prothrombin time" of normal platelet rich, normal platelet poor, and both types of hemophilic plasma. (In this and subsequent tables the clotting times are averages of at least two determinations and are in seconds.)

The clotting times of "silicone" and "glass activated" samples of normal plasma recalcified in the presence of three different "thromboplastic" agents are given in Table IV. The large difference in the "cephalin" clotting times reflects the fact that "cephalin" reacts with the antihemophilic $B$ factor. The variation which glass can cause in the "cephalin" clotting time of normal plasma must be remembered when this test is used, as advocated (23), for the presumptive diagnosis of hemophilia. However, the main point of this table is to show that the longer clotting time of "silicone" plasma which persists in the presence of strong brain thromboplastin disappears, as Tocantins noted $(1,2)$, when Russell viper venom is the "thromboplastic" agent. We have shown (29) that the clotting activity of Russell viper venom is independent of the proconvertin content of plasma. Therefore, if the shortening produced by glass is not manifest in the presence of viper 
TABLE IV

The clotting times of "silicone" and "glass activated" plasma when "cephalin," brain thromboplastin and Russell viper venom are used as the "thromboplastic" agents

\begin{tabular}{lcc}
\hline \hline & \multicolumn{2}{c}{ Clotting time (seconds) } \\
\cline { 2 - 3 } \multicolumn{1}{c}{ Thromboplastic agent } & $\begin{array}{c}\text { "Silicone" } \\
\text { plasma }\end{array}$ & $\begin{array}{c}\text { "Glass } \\
\text { activated" } \\
\text { plasma }\end{array}$ \\
\hline "Cephalin" 0.11 gm. \% & 197 & 36.5 \\
Saline brain extract & 14.5 & 9.5 \\
Russell viper venom & 9.5 & 10.5 \\
\hline
\end{tabular}

venom, suspicion arises that the shortening is due to proconvertin activation.

\section{The proof that glass increases proconvertin activity}

Examples are given in Table $\mathrm{V}$ of the results obtained when normal "silicone" and "glass activated" plasmas were analyzed in the $P \& P$, proconvertin, prothrombin, and proaccelerin systems. These data show that the shortening produced by glass in the presence of strong brain thromboplastin is due to the activation of proconvertin. When, as in the prothrombin and proaccelerin systems, an excess of proconvertin in other reagents masks a change in the proconvertin content of the test sample, no difference is found between "silicone" and "glass activated" plasma.

As Table VI shows, a comparable increase in proconvertin activity was obtained when hemophilia A, hemophilia B, and parahemophilia plasmas were tested. The activity of serum prepared by adding brain thromboplastin to blood and aged in glass for 5 days at $6^{\circ} \mathrm{C}$. could not be increased by glass powder. However, glass could activate serum prepared in the same manner but stored frozen at $-20^{\circ} \mathrm{C}$. for one year. When "silicone" congenital hypoproconvertinemia plasma was shaken with glass powder, its very long procon-

TABLE V

The effect of shaking with quartz glass poroder upon the $P$ \& $P$, proconvertin, prothrombin and proaccelerin clotting times of normal plasma

\begin{tabular}{|c|c|c|c|c|}
\hline \multirow[b]{2}{*}{ Determination } & \multicolumn{2}{|c|}{ Sample 1} & \multicolumn{2}{|c|}{ Sample 2} \\
\hline & "Silicone" & $\begin{array}{l}\text { "Glass } \\
\text { act." }\end{array}$ & "Silicone" & "Glass \\
\hline $\begin{array}{l}\text { P \& } \mathbf{P} \\
\text { Proconvertin } \\
\text { Prothrombin } \\
\text { Proaccelerin }\end{array}$ & $\begin{array}{l}31.0 \\
32.0 \\
30.0 \\
36.5\end{array}$ & $\begin{array}{l}26.0 \\
24.5 \\
32.0 \\
35.0\end{array}$ & $\begin{array}{l}30.5 \\
36.5 \\
31.5 \\
29.0\end{array}$ & $\begin{array}{l}24.0 \\
28.5 \\
32.0 \\
29.5\end{array}$ \\
\hline
\end{tabular}

vertin time was reduced by the activation of the small amount of proconvertin which this plasma contains.

The proconvertin times of varying dilutions of "silicone" and "glass activated" plasma were also measured when the dilutions were made not in diluting fluid but in congenital hypoproconvertinemia plasma. This provided an increasing relative excess of all clotting factors except proconvertin with increasing dilution of the test plasmas. The results, when plotted upon double logarithmic paper as in Figure 1, gave lines with parallel slopes. The relative difference between the "silicone" and "glass activated" plasmas persisted for all dilutions. Some workers have claimed that

TABLE VI

The effect of shaking with quartz glass powder upon the proconvertin time of different kinds of plasma and serum

\begin{tabular}{|c|c|c|}
\hline \multirow[b]{2}{*}{ Material } & \multicolumn{2}{|c|}{$\begin{array}{l}\text { Proconvertin clotting time } \\
\text { (seconds) }\end{array}$} \\
\hline & $\begin{array}{l}\text { "Silicone" } \\
\text { plasma }\end{array}$ & $\begin{array}{l}\text { "Glass } \\
\text { activated" } \\
\text { plasma }\end{array}$ \\
\hline $\begin{array}{l}\text { Hemophilia A plasma } \\
\text { Hemophilia B plasma } \\
\text { Parahemophilia plasma* } \\
\text { Serum aged } 5 \text { days at } 6^{\circ} \mathrm{C} \text {. } \\
\text { Serum frozen }-20^{\circ} \mathrm{C} \text {. for }\end{array}$ & $\begin{array}{l}34.5 \\
36.5 \\
31.5 \\
29.5\end{array}$ & $\begin{array}{l}24.0 \\
26.5 \\
26.5 \\
29.5\end{array}$ \\
\hline $\begin{array}{l}1 \text { year } \\
\text { Congenital hypoprocon- } \\
\text { vertinemia plasma }\end{array}$ & 35.5 & 30.0 \\
\hline
\end{tabular}

* "Silicone" parahemophilia plasma was not available. The comparison had to be made between parahemophilia plasma taken and stored frozen in glass and analyzed immediately after thawing with the same plasma shaken with glass powder before analysis.

glass activates prothrombin (12). At the 1 per cent dilution the contribution of the prothrombin in the test plasma to the total prothrombin in the clotting mixture is insignificant yet the relative difference between the clotting times of "silicone" and "glass activated" plasma is as great as with the undiluted samples which provide 50 per cent of the prothrombin in the clotting mixture. In our opinion, this experiment eliminates the possibility that the factor activated by glass and measured in the presence of strong brain extract can be anything but proconvertin.

\section{The extent of the increase in proconvertin ac- tivity produced by glass powder}

The extent of the increase in proconvertin activity which glass powder may produce is meas- 


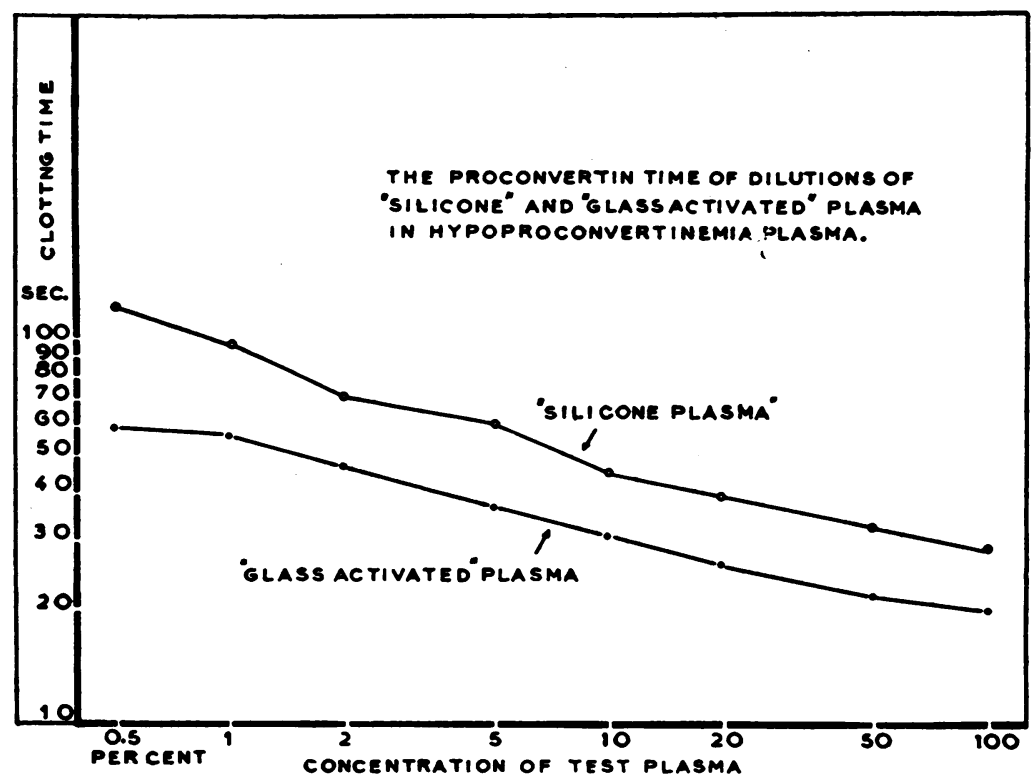

Fig. 1.

ured best when the proconvertin content of the plasma has been depressed by Dicumarolब. In one group of experiments the effect of exposure to glass powder upon the Quick "prothrombin time" of "silicone" Dicumarol plasma was compared with effect of adding prothrombin free serum to the Dicumarol plasma. Quick "prothrombin times" were done upon the following combinations: $0.2 \mathrm{ml}$. of "silicone" plasma plus $0.2 \mathrm{ml}$. of buffer; $0.2 \mathrm{ml}$. of "glass activated" plasma plus $0.2 \mathrm{ml}$. of buffer; and $0.2 \mathrm{ml}$. of "silicone" plasma plus $0.2 \mathrm{ml}$. of prothrombin free serum. The striking shortening of the Quick time by glass powder is readily apparent from the data shown in the upper columns of Table VII. Glass activation approached the effect of adding serum to "silicone" Dicumarol ${ }^{\circ}$ plasma.

The data in the lower columns of Table VII are the proconvertin times of the same "silicone" and "glass activated" Dicumarol plasmas. The percentages were obtained from a dilution curve made with normal "silicone" plasma. These data show that glass activation can increase proconvertin activity about three-fold or greater and can mask a moderate reduction in the proconvertin content by Dicumarol All but one of these plasmas appear to contain an excess of proconvertin when compared with normal "silicone" plasma.

\section{The means by which glass powder activates proconvertin}

There is insufficient evidence to be certain of how glass increases proconvertin activity in citrated plasma. As discussed earlier, neither the prior activation of the antihemophilic $B$ factor nor the generation of a small amount of blood thromboplastin is the mechanism. Minute amounts of thrombin, either as a contaminant on the glass or somehow formed in the citrated plasma on the addition of glass powder, can not be implicated.

\section{TABLE VII}

The extent of the increase in proconvertin actioity of Dicumarol ${ }^{\circ}$ plasma produced by glass activation

\begin{tabular}{|c|c|c|c|c|c|}
\hline \multirow{2}{*}{$\begin{array}{l}\text { Type of test } \\
\text { Modified Quick test } \\
\text { Clotting times (sec.) }\end{array}$} & \multicolumn{5}{|c|}{ Plasma sample } \\
\hline & 1 & 2 & 3 & 4 & 5 \\
\hline $\begin{array}{l}\text { "Silicone" plasma } \\
\text { plus buffer } \\
\text { "Glass act." plasma }\end{array}$ & 36.5 & 33.0 & 59.0 & 34.5 & 34.0 \\
\hline $\begin{array}{l}\text { plus buffer } \\
\text { "Silicone" plasma }\end{array}$ & 23.0 & 23.5 & 36.5 & 26.0 & 22.0 \\
\hline+ serum & 21.0 & 20.0 & 25.5 & 22.5 & 19.0 \\
\hline \multicolumn{6}{|l|}{ Proconvertin test } \\
\hline $\begin{array}{l}\text { "Silicone" plasma } \\
\text { Clotting time (sec.) } \\
\text { Per cent } \\
\text { "Glass act." plasma }\end{array}$ & $\begin{array}{l}42.0 \\
54\end{array}$ & $\begin{array}{l}47.0 \\
36\end{array}$ & $\begin{array}{l}59.5 \\
15\end{array}$ & $\begin{array}{l}43.0 \\
49\end{array}$ & $\begin{array}{l}38.5 \\
72\end{array}$ \\
\hline $\begin{array}{l}\text { Clotting time (sec.) } \\
\text { Per cent }\end{array}$ & $\begin{array}{l}32.5 \\
130\end{array}$ & $\begin{array}{l}32.0 \\
150\end{array}$ & $\begin{array}{l}39.5 \\
66\end{array}$ & $\begin{array}{l}29.5 \\
190\end{array}$ & 300 \\
\hline
\end{tabular}


The pure quartz powder was used only once and had never been in contact with blood before. Furthermore, as Table VI shows, glass powder increases the proconvertin activity of old frozen serum. The addition of a little thrombin to such serum did not increase its proconvertin activity. Ordinary glass contains about 5 per cent calcium, but quartz powder is pure silicone dioxide and can not add calcium to the plasma.

Gortner and Biggs pointed out (30) that glass possesses a negative electrical charge and can adsorb positively charged substances by electrostatic attraction. Proconvertin, which resembles prothrombin in its physico-chemical properties, has an acid isoelectric point and therefore possesses an overall negative charge at the $\mathrm{pH}$ of the blood. A positively charged inhibitor could be loosely bound to proconvertin. If so, the addition of glass powder to plasma could pull away the positively charged inhibitor from the main body of the proconvertin molecule.

This hypothesis gains theoretical support from the observation that heparin will prevent the activation of proconvertin by glass. Ware and Stragnell (31) had noted that the shortening of the "prothrombin time" of plasma which stands in glass tubes could be prevented by adding $100 \mathrm{mi}$ crograms of heparin to each $\mathrm{ml}$. of the usual 0.1 $M$ oxalate anticoagulant. The experiments summarized in Table VIII reveal that 50 micrograms of heparin per $\mathrm{ml}$. of plasma will prevent or greatly reduce the activation of proconvertin by glass powder. The addition of heparin after the plasma has been shaken with glass powder does not "deactivate" previously formed active proconvertin. These findings could mean that the nega-

TABLE VIII

The effect of heparin (50 micrograms per ml. plasma) upon the proconvertin activity of "silicone" and "glass activated" plasma

\begin{tabular}{|c|c|c|c|}
\hline \multirow[b]{3}{*}{ Type of plasma } & \multirow{2}{*}{\multicolumn{3}{|c|}{$\begin{array}{c}\begin{array}{c}\text { Proconvertin clotting } \\
\text { time (sec.) }\end{array} \\
\text { Sample }\end{array}$}} \\
\hline & & & \\
\hline & 1 & 2 & 3 \\
\hline \multirow{2}{*}{$\begin{array}{l}\text { "Silicone" plasma } \\
\text { No heparin } \\
\text { Added heparin } \\
\text { "Glass activated" plasma } \\
\text { No heparin } \\
\text { Heparin before glass act. } \\
\text { Heparin after glass act. }\end{array}$} & $\begin{array}{l}34.0 \\
36.0\end{array}$ & $\begin{array}{l}31.0 \\
31.5\end{array}$ & $\begin{array}{l}34.0 \\
36.0\end{array}$ \\
\hline & $\begin{array}{l}27.0 \\
34.5 \\
26.5\end{array}$ & $\begin{array}{l}25.5 \\
31.0 \\
28.0\end{array}$ & $\begin{array}{l}27.0 \\
32.0 \\
28.5\end{array}$ \\
\hline
\end{tabular}

TABLE IX

The proconvertin activity of "silicone" and "glass activated" plasmas and their eluates from tricalcium phosphate

\begin{tabular}{lc}
\hline \hline \multicolumn{1}{c}{ Material tested } & $\begin{array}{c}\text { Proconvertin } \\
\text { clotting time } \\
(\text { sec.) }\end{array}$ \\
\hline "Silicone" plasma & 37.0 \\
Eluate from "silicone" plasma & 35.0 \\
"Glass activated" plasma & 25.0 \\
Eluate from "glass act." plasma & 25.0 \\
\hline
\end{tabular}

tively charged heparin combines with a positively charged inhibitor to neutralize it and thereby prevent its adsorption onto the glass.

Fiala (5) described an inhibitor removed from plasma by glass or other negatively charged materials and also removed together with "prothrombin" by the usual "prothrombin" adsorbents (calcium phosphate, barium carbonate, etc.). A1though Fiala was unable to elute the inhibitor from glass he was able to elute it from barium carbonate and to demonstrate its effects after acid destruction of the accompanying "prothrombin." Fiala and Roth originally believed that this inhibitor acted against prothrombin, but later stated (6) that it might act upon proconvertin (stable conversion factor).

Evidence that a proconvertin inhibitor is removed with proconvertin by the "prothrombin" adsorbent tricalcium phosphate is provided by the following experiment. "Silicone" and "glass activated" plasmas were each agitated with $2.6 \mathrm{mg}$. per ml. of tricalcium phosphate for ten minutes. Each tricalcium phosphate sediment, after washing, was mixed with a small amount of $0.2 \mathrm{M}$ sodium citrate. Each citrate eluate was then made up with veronal buffer to the citrate concentration and volume of the original plasma. Silicone technique was used for the eluate from the silicone plasma. The proconvertin times of the original plasmas and their eluates were then compared. As shown in Table IX, the difference between the proconvertin activity of "silicone" and "glass activated" plasma was found to persist in their eluates. This finding, which strongly suggests that tricalcium phosphate adsorbes a proconvertin inhibitor with proconvertin from "silicone" plasma, leads us to believe that the activation of proconvertin by glass may be due to the adsorption onto the glass of the inhibitor described by Fiala. 
5. The relation between the activation of proconvertin by glass and by thromboplastin plus calcium during clotting

Although glass does not increase proconvertin activity through blood thromboplastin formation, the addition of tissue thromboplastin to blood will increase the proconvertin activity of the resultant serum (22). Apparently proconvertin can be activated in at least two ways: 1) By an action of glass which can occur in decalcified plasma and therefore begins as soon as citrated blood is placed in a glass tube; and 2) by an action of thromboplastin which cannot begin until the plasma has been recalcified. The reason for the difference between the clotting time of "silicone" and "glass activated" plasma in the presence of strong brain thromboplastin is that some preactivated proconvertin is present in the "glass activated" plasma whereas the activation in "silicone" plasma by thromboplastin and calcium is not initiated until after recalcification.

The following experiment suggests that the same inhibitor is removed by glass on standing as by thrombolpastin plus calcium during clotting. Nine and one-half $\mathrm{ml}$. of blood were collected into each of two silicone tubes. One tube contained $1 / 2 \mathrm{ml}$. of brain extract thromboplastin; the other contained $1 / 2 \mathrm{ml}$. of buffer. The contents of each tube were mixed by tilting once and stood undisturbed at $37^{\circ} \mathrm{C}$. for one hour after clotting. The serums were transferred to silicone coated tubes which contained $0.2 \mathrm{ml}$. of sodium citrate per $\mathrm{ml}$. of serum. The proconvertin activity of each serum was measured with silicone technique in a system modified by the substitution of accelerin reagent for the usual proaccelerin reagent. This eliminated differences due to the accelerin content of the two serums. Each serum was then

TABLE $\mathbf{X}$

The effect of shaking with quartz glass powder upon the proconvertin activity of serum prepared from blood clotted in silicone coated tubes with and without exogenous thromboplastin

\begin{tabular}{lcc}
\hline \hline \multirow{2}{*}{$\begin{array}{c}\text { Serum from blood } \\
\text { clotted }\end{array}$} & \multicolumn{2}{c}{$\begin{array}{c}\text { Proconvertin clotting } \\
\text { time (sec.) }\end{array}$} \\
\cline { 2 - 3 } & $\begin{array}{c}\text { Before } \\
\text { "glass act." }\end{array}$ & $\begin{array}{c}\text { After } \\
\text { "glass act." }\end{array}$ \\
\hline $\begin{array}{lcc}\text { With added thrombopl. } \\
\text { Without thrombopl. }\end{array}$ & 17.0 & 17.0 \\
\hline
\end{tabular}

shaken with $1 / 4$ its volume of glass powder and the proconvertin content measured again.

The results, shown in Table $X$, reveal that the proconvertin of "silicone" plasma is completely activated during clotting in the presence of strong thromboplastin. A glass surface is not needed for this activation and no further activation is produced by shaking the serum with glass powder. In contrast, when the blood clotted in a silicone coated tube without added thromboplastin, little or no activation of proconvertin occurred. This is because only a little blood thromboplastin is formed during clotting in "silicone" coated tubes for there is little active antihemophilic B factor. The proconvertin activity of this serum was greatly increased by subsequent shaking with glass powder. This strongly suggests that glass and thromboplastin remove the same inhibitor from proconvertin.

The increase in proconvertin activity produced during clotting by strong thromboplastin is greater than that which glass powder can produce. "Glass activated" plasma repeatedly gave a clotting time of about 22 seconds in this system, whereas the serum from blood clotted with exogenous thromboplastin gave clotting times in the 15 to $17 \mathrm{sec}-$ ond range even after standing for six hours. It would appear as though glass adsorption is not capable of producing the maximum activation of proconvertin.

\section{Proconvertin nomenclature}

These experiments have led us to modify our terms for proconvertin activity. Proconvertin in blood before contact with glass appears to be combined with an inhibitor and may therefore be called inactive proconvertin. When blood is placed in a glass tube the inhibitor is slowly adsorbed onto the glass with the formation of increasing amounts of active proconvertin. Therefore, unless prepared with careful silicone technique, plasma will contain a mixture of inactive proconvertin and active proconvertin. Plasma examined soon after the blood is drawn, however, will contain mainly inactive proconvertin.

When blood is clotted with large amounts of thromboplastin two changes occur. The thromboplastin will convert the remaining inactive proconvertin to active proconvertin. In addition, some of the active proconvertin is believed to re- 
act with the thromboplastin to form a new and more powerful activity which has been called convertin. Convertin is a qualitatively different activity as can be shown (27) by its immunity to the action of the lipid antithromboplastin of Tocantins (1-3). It is a combination of thromboplastin with active proconvertin in the presence of calcium and should not be confused with the clotting activity of a mixture of thromboplastin and active proconvertin.

Fresh serum from blood clotted with strong thromboplastin will contain a mixture of convertin and active proconvertin. The convertin activity is thought to disappear within a few hours, probably due to the presence of an anti-convertin. The serum will then contain only active proconvertin. In contrast, serum prepared by clotting blood in a silicone coated tube, that is, with no exposure to glass and with little thromboplastin formation, will contain primarily inactive proconvertin. This inactive proconvertin can be activated by glass contact.

This concept of inactive and active proconvertin seems a more useful way to think about proconvertin than to attempt a rigorous distinction between a plasma and serum form. For by variation of the conditions of preparation, either inactive or active proconvertin may predominate in either the plasma or the serum.

The fact that glass activates both the antihemophilic B factor and proconvertin does not have to mean that both substances circulate in combination with the same inhibitor. However, one is impressed with the similar properties of these two clotting factors. They are both adsorbed by the "prothrombin" adsorbents and eluted by sodium citrate. They both persist in serum where their activity is usually greater than in plasma. It may be that the same substance inhibits them both.

\section{SUMMARY}

1. The clotting behaviour of platelet poor plasma exposed only to silicone surfaces was compared with that of plasma which had been shaken with quartz glass powder. The effect of such glass activation upon the various plasma clotting factors was measured in one-stage assays for antihemophilic A factor, antihemophilic B factor, prothrombin, proconvertin and proaccelerin.
2. Exposure to glass increased the activity of the antihemophilic B factor and proconvertin. No change in antihemophilic A factor, prothrombin or proaccelerin activity was found.

3. Glass powder increased proconvertin activity three-fold or more. Moderate reductions in the proconvertin content of plasma due to Dicumarolo were masked.

4. Glass powder could not activate proconvertin in the presence of heparin, but heparin could not "deactivate" previously formed active proconvertin.

5. A possible mechanism for the glass activation of the antihemophilic B factor and proconvertin is the adsorption of a positively charged inhibitor onto the negatively charged glass.

6 . The relation between the activation of proconvertin by glass and by thromboplastin plus calcium has been examined. Proconvertin has been defined as inactive proconvertin or active proconvertin, rather than as a plasma or serum activity.

\section{ACKNOWLEDGMENT}

We wish to thank Nurse Solveig Mikkelsen for her technical assistance.

\section{REFERENCES}

1. Tocantins, L. M., Influence of the contacting surface on the coagulability and anticephalin activity of normal and hemophilic plasmas. Am. J. Physiol., 1945, 143, 67.

2. Tocantins, L. M., Holburn, R. R., and Carroll, R. T., Response of plasma to excess of thromboplastin as a measure of prothrombin activity. Proc. Soc. Exper. Biol. \& Med., 1951, 76, 623.

3. Tocantins, L. M., Hemophilic syndromes and hemophilia. Blood, 1954, 9, 281.

4. Fiala, S., A thermolabile inhibitor of plasma coagulation. Nature, 1951, 167, 279.

5. Fiala, S., On the role of a protein inhibitor in the first stage of blood coagulation. Arch. internat. de physiol., 1951, 58, 386.

6. Fiala, S., and Roth, K., Platelets and the thromboplastic system of blood coagulation. Arch. internat. de physiol., 1953, 61, 205.

7. Conley, C. L., Hartmann, R. C., and Morse, W. I., II, The clotting behaviour of human "plateletfree" plasma: Evidence for the existence of a "plasma thromboplastin." J. Clin. Invest., 1949, 28, 340.

8. Hartmann, R. C., Conley, C. L., and Lalley, J. S., Studies on the initiation of blood coagulation. I. The relationship of platelets to the clot-pro- 
moting effect of glass surfaces. Bull. Johns Hopkins Hosp., 1949, 85, 231.

9. Ratnoff, O. D., and Conley, C. L., The rôle of surface and of calcium in the coagulation of a globulin fraction of platelet-deficient plasma. Bull. Johns Hopkins Hosp., 1951, 89, 245.

10. Quick, A. J., and Epstein, E., Thromboplastic activity in human blood. J. Applied Physiol., 1952, 4, 840 .

11. Biggs, R., Douglas, A. S., and Macfarlane, R. G., The initial stages of blood coagulation. J. Physiol., 1953, 122, 538 .

12. Quick, A. J., and Stefanini, M., The state of component A (prothrombin) in human blood; evidence that it is partly free and partly in an inactive or precursor form. J. Lab. \& Clin. Med., 1949, 34, 1203.

13. Quick, A. J., The pathological physiology of hemorrhagic conditions. Bull. New York Acad. Med., 1953, 29, 226.

14. Rapaport, S. I., Aas, K., and Owren, P. A., The increased coagulability of plasma exposed to glass. Scandinav. J. Clin. and Lab. Invest., 1954, 6, 82.

15. Lenggenhager, K., quoted in Owren, P. A., The coagulation of blood; Investigations on a new clotting factor, Oslo, J. Chr. Gundersen, 1947, p. 53.

16. Lozner, E. L., Taylor, F. H. L., and MacDonald, H., The effect of foreign surfaces on blood coagulation. J. Clin. Invest., 1942, 21, 241.

17. Aggeler, P. M., White, S. G., Glendening, M. B., Page, E. W., Leake, T. B., and Bates, G., Plasma thromboplastin component (PTC) deficiency: A new disease resembling hemophilia. Proc. Soc. Exper. Biol. \& Med., 1952, 79, 692.

18. Aggeler, P. M., White, S. G., and Spaet, T. H., Deuterohemophilia: plasma thromboplastin factor B deficiency. Plasma thromboplasma component (PTC) deficiency, Christmas disease, hemophilia B. Blood, 1954, 9, 246.

19. Lewis, M. L., and Ware, A. G., The mechanism of action of human accelerator globulin and its relation to other clotting factors. Blood, 1954, 9, 520.

20. Alexander, B., and Landwehr, G., Evolution of a prothrombin conversion accelerator in stored human plasma and prothrombin fractions. Am. J. Physiol., 1949, 159, 322.

21. Biggs, R., and Macfarlane, R. G., Human Blood Coagulation and Its Disorders, Oxford, Blackwell Scientific Publications, 1953.

22. Alexander, B., DeVries, A., and Goldstein, R., A factor in serum which accelerates the conversion of prothrombin to thrombin. II. Its evolution with special reference to the influence of conditions which affect blood coagulation. Blood, 1949, 4, 739.

23. Langdell, R. D., Wagner, R. H., and Brinkhous, $\mathrm{K}$. M., Effect of antihemophilic factor on onestage clotting tests; a presumptive test for hemophilia and a simple one-stage antihemophilic factor assay procedure. J. Lab. \& Clin. Med., 1953, 41, 637.

24. Owren, P. A., and Aas, K., The control of Dicumarol therapy and the quantitative determination of prothrombin and proconvertin. Scandinav. J. Clin. and Lab. Invest., 1951, 3, 201.

25. Owren, P. A., Prothrombin and accessory factors. Clinical significance. Am. J. Med., 1953, 14, 201.

26. Milstone, J. H., The problem of lipoid thromboplastins. Yale J. Biol. \& Med., 1950, 22, 675.

27. Rapaport, S. I., Aas, K., and Owren, P. A., The lipid inhibitor of brain: mechanism of its anticoagulant action and its comparison with soybean inositol phosphatide inhibitor. J. Lab. \& Clin. Med., 1954, 44, 364.

28. Owren, P. A., A quantitative one-stage method for the assay of prothrombin. Scandinav. J. Clin. and Lab. Invest., 1949, 1, 81.

29. Rapaport, S. I., Aas, K., and Owren, P. A., The coagulant activity of Russell viper venom. Scandinav. J. Clin. and Lab. Invest., 1954, 6, 81.

30. Gortner, R. A., and Biggs, D. R., Glass surfaces versus paraffin surfaces in blood-clotting phenomena-a hypothesis. Proc. Soc. Exper. Biol. \& Med., 1928, 25, 820.

31. Ware, A. G., and Stragnell, R., An improved onestage prothrombin method. Am. J. Clin. Path., 1952, 22, 791. 